\title{
Nutritional Assessment of Hibiscus rosa sinensis Flower, Formulation and Popularization of Hibiscus Flower based Products
}

\author{
M. K. Sheeba ${ }^{1 *}$ and B. Niveditha ${ }^{2}$ \\ 'Assistant Professor, Department of Foods and Nutrition, Vellalar College for Women, \\ Erode, Tamilnadu \\ ${ }^{2}$ PG Student, Vellalar College for Women, Erode, Tamilnadu
}

\begin{abstract}
Medicinal plants have been used in virtually all cultures as a source of medicine, since times immemorial. Hibiscus rosa sinensis Linn. (Family Malvaceae) is a plant which is widely distributed throughout the world. Pharmacological studies showed that flowers of $H$. rosa sinensis have numerous actions including antibacterial, wound healing, antidepressant, cardiac and antioxidant effects. This study aimed to estimate the nutritional value, phytochemical and physicochemical properties and microbial counts of hibiscus flowers (both fresh and dry). The result showed that the nutrient contents of hibiscus dry powder was higher than the hibiscus syrup. The chemical constituents present in the methanol and $50 \%$ aqueous - alcoholic extracts of fresh and dried hibiscus flower were alkaloids, glycosides, carbohydrates, phytosterols, polyphenols, tannins, saponins, flavonoids and proteins and amino acids and the constituents steroids, terpenoids and triterpenoids were absent. The physico-chemical parameters like total ash, acid insoluble ash, water soluble ash and sulphated ash were found to be high in dried flowers than fresh flowers. The bacterial count of hibiscus flower powder indicates that the sample stored in the ziplock polypack was minimum than in the plastic container and the yeast and mould count indicates that the sample stored in the plastic container was minimum than in the ziplock polypack. The hibiscus syrup and powder based products were also developed to create nutritional awareness among the adolescent girls.
\end{abstract}

Keywords: Bacterial Count, Chemical Constituents, Hibiscus rosa sinensis, Nutrient Contents, Nutritional Awareness

\section{Introduction}

The Hibiscus rosa sinensis, a highly potential, functional and valuable medicinal plant, has been reported in the ancient medicinal literature with beneficial effects in various disorders of humans ${ }^{1}$. Hibiscus rosa sinensis flowers are reported to contain quercetin, anthocyanins, flavonoids, cyclopeptide alkaloid and vitamins ${ }^{2}$. They possess anti-tumor, anti-fertility effect, analgesic, antipyretic, anti-inflammatory, anti-viral, anti-diabetic and hypoglycemic activities ${ }^{3}$.

The hibiscus flower is extensively mentioned in Ayurveda and siddha systems and continue to be a prominent herbal remedy of indigenous practices across the world to treat hair fall, piles, hemorrhage, menorrhagia, leucorrhoea, dysuria, hypertension, cough, diseases of pittam and as emmenagogue, abortifacient and contraceptive $e^{4}$.

An infusion of the petal is widely used in Ayurvedic medicine in India as a demulcent refrigerant drink in fever ${ }^{5}$.

\section{Materials and Methods}

Hibiscus rosa sinensis is a conspicuous, perennial, ornamental shrub, red in colour, 4-6 inches in diameter. 
The petals are thin and slightly crinkly and look like tissue paper and its corolla consists of 5 petals ${ }^{6}$. The hibiscus flowers needed for the present study were collected from the surroundings. The flowers were selected carefully without any damage or insect infestation for processing.

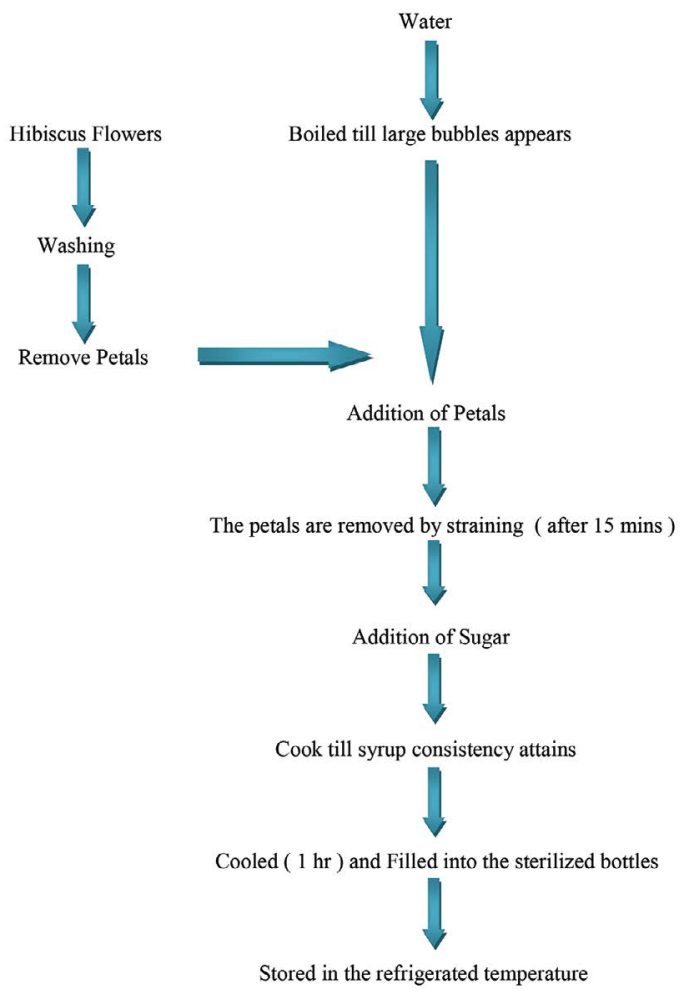

Figure 1. Preparation of hibiscus syrup.



Figure 2. Preparation of hibiscus powder.

\subsection{Analysis of Nutritive Value}

In the present study, the nutritive value of both syrup and the dry powder made from the hibiscus flower such as Calories, Proteins, Fat, Fibre, Vitamin-A, Vitamin-C, Sodium, Phosphorus, Potassium, Iron and Calcium were analyzed quantitatively.

\subsection{Analysis of Chemical Constituents}

The medicinal value of a plant depends on the nature of the chemical constituents present. The chemical constituents which is responsible for the therapeutic effect is called as the active principle 7 . In the present study, some of the chemical constituents such as Tannins, flavonoids, triterpenoids, polyphenols, alkaloids, anthocyanins and saponins were analyzed in both the fresh and dry hibiscus flowers.

\subsection{Analysis of Physicochemical Parameters}

The quantitative analysis of the physicochemical parameters such as moisture, total ash, acid insoluble ash, water soluble ash, sulphated ash, swelling index and foaming index were determined in the fresh and dry hibiscus flowers.

\subsection{Formulation of Products}

Many food products are made by combining raw materials in specific proportions in a formulation and research on the effects of various formulations on product qualities is common in product design.

The products such as rasgulla, gulab jamun and lemonade were prepared by using hibiscus syrup and products like Podi (mix), pudding and milkshake were prepared by using dry hibiscus powder. The formulated recipes were organoleptically evaluated to estimate their acceptability using 5 points Hedonic Scale.

\subsection{Popularization of Formulated Products}

The nutritional awareness was conveyed through lecture method, with the help of teaching aids. Pamphlets, booklets and power point presentation were prepared and used to give counseling for 30 adolescent girls selected for the study in Vellalar College for Women, Thindal, Erode.

\subsection{Assessment of Storage Stability}

The microbial count namely TBC (Total Bacterial Count), Total yeast and mould count in the dried hibiscus 
powder was evaluated initially, $15^{\text {th }}$ day and $30^{\text {th }}$ days of storage.

\section{Results and Discussion}

\subsection{Nutrient Content of Hibiscus rosa sinensis Syrup and Powder}

There was a wide range of difference in the nutritive values of energy, carbohydrates, fibre and calcium contents between the syrup and powder. The nutrient contents of hibiscus dry powder was found to be high than the nutrient content of hibiscus syrup.

\subsection{Comparison of Nutrient Content of Formulated Products}

The nutrient content of all the formulated products were analyzed and discussed in this study. Table 2 depicts the products based on the decreasing trend of nutrients.

This table revealed that among all the products mix (podi) made from hibiscus powder was found to be rich in most of the nutrients and the lemonade (sherbat) made from syrup was found to be the least in all nutritive values. 3.3 Chemical Constituents in Fresh and Dry Hibiscus Flowers

Table 1. Nutrient content of hibiscus syrup and dry powder (100 g)

\begin{tabular}{|c|c|c|c|c|}
\hline S.No & NUTRIENTS & UNITS & SYRUP & POWDER \\
\hline 1 & Energy & K.Cal & 159.2 & 353 \\
\hline 2 & Carbohydrates & $\mathrm{g}$ & 39.76 & 86.3 \\
\hline 3 & Proteins & $\mathrm{g}$ & 0.052 & 3.9 \\
\hline 4 & Fat & $\mathrm{g}$ & 0.08 & 3.9 \\
\hline 5 & Fibre & $\mathrm{g}$ & 0.312 & 15.7 \\
\hline 6 & Calcium & $\mathrm{mg}$ & 5.6 & 39 \\
\hline 7 & Phosphorus & $\mathrm{mg}$ & 5.8 & 265 \\
\hline 8 & Iron & $\mathrm{mg}$ & 0.402 & 1.7 \\
\hline 9 & Vit - C & $\mathrm{mg}$ & 0.84 & 3.9 \\
\hline
\end{tabular}

Table 2. Comparison of nutrient content of formulated products

\begin{tabular}{|c|c|c|c|c|c|c|c|}
\hline \multirow{2}{*}{ S.No } & \multirow{2}{*}{ Nutrients } & \multicolumn{7}{|c|}{ Sequence of the Products } \\
\cline { 3 - 8 } & & I & II & III & IV & V & VI \\
\hline 1 & Energy & GJ & MX & MS & PUD & RAS & LEM \\
\hline 2 & Carbohydrates & MX & MS & PUD & GJ & RAS & LEM \\
\hline 3 & Proteins & MX & PUD & RAS & GJ & MS & LEM \\
\hline 4 & Fat & GJ & MX & PUD & RAS & MS & LEM \\
\hline 5 & Fibre & MX & PUD & MS & GJ & RAS & LEM \\
\hline 6 & Calcium & MX & RAS & PUD & MS & GJ & LEM \\
\hline 7 & Phosphorus & MX & PUD & MS & RAS & GJ & LEM \\
\hline 8 & Iron & MX & GJ & RAS & PUD & LEM & MS \\
\hline 9 & Carotene & MX & RAS & PUD & MS & GJ & LEM (NO) \\
\hline 10 & Vit - C & MX & RAS & PUD & GJ & LEM & MS \\
\hline
\end{tabular}
RAS - Rasgulla
GJ - Gulab Jamun
LEM - Lemonade
MX - Mix
PUD - Pudding
MS - Milkshake

The chemical constituents (phytochemicals) were 
analyzed in both fresh and dry Hibiscus rosa sinensis flowers. Chemical tests are conducted on the methanolic extract and also 50\% aqueous-alcoholic extract of the powdered form of the samples using standard methods.

The methanol extract of hibiscus flower contain varied type of phytochemical compounds which include, alkaloids, glycosides, carbohydrates, phytosterols, polyphenols, tannins, saponins, flavonoids and proteins and amino acids. The $50 \%$ aqueous-alcoholic extract of hibiscus flower contain carbohydrates, phytosterols, flavonoids, saponins, polyphenols, proteins and aminoacids.

Steroids, terpenoids and triterpenoids were absent in both the methanol and 50\% aqueous - alcoholic extract of fresh and dried hibiscus flowers.

\subsection{Physico Chemical Parameters in Fresh and Dry Hibiscus Flowers}

The physicochemical properties such as total ash, acid insoluble ash, water insoluble ash, sulphated ash, water soluble extractive value, alcohol soluble extractive value, moisture content, swelling index and foaming index were determined in both the fresh and dry Hibiscus rosa sinensis flowers.

The total ash content of dry flower was higher than fresh flowers. Acid insoluble and water insoluble contents and also the sulphated ash value of both fresh and dried flowers were found to be more or less similar. Water insoluble extractive value and Alcohol soluble extractive value of fresh flowers were slightly higher than that of dry flowers. Swelling index and foaming index of both fresh and dry flowers were also found to be the same.

\subsection{Storage Stability of Dry Hibiscus}

\section{Powder}

The flower extracts had stronger antibacterial effects than that of leaves at the applied doses of 50 and 100 $\mathrm{mg}$ and raises the possibility of using the extracts as antimicrobial agents in treating pathological conditions caused by $S$. aureus and S. typhimurium infection ${ }^{8}$.

\subsubsection{Bacterial Count}

The above table showed that there was slight increase in the bacterial count during storage which may be due to the improper storage of the sample. The sample stored in the ziplock polypack shows reduced bacterial growth than stored in the plastic container.

\subsubsection{Yeast and Mould Count}

The above table showed that there was a slight increase in the total yeast and mould count of the sample stored in

Table 3. Phytochemical analysis of fresh and dry HRS flowers

\begin{tabular}{|c|c|c|c|c|c|}
\hline \multirow{2}{*}{ S.No } & \multirow{2}{*}{ Test For } & \multicolumn{2}{|c|}{ Methanol Extract } & \multicolumn{2}{c|}{$50 \%$ Aqueous-Alcoholic } \\
& & Fresh & Dried & Fresh & Dried \\
\cline { 2 - 5 } & Alkaloids & + & + & - & - \\
\hline 1 & Glycosides & + & + & - & - \\
\hline 2 & Carbohydrates & + & + & + & + \\
\hline 3 & Phytosterols & + & + & - & + \\
\hline 4 & Steroids & - & - & + & + \\
\hline 5 & Flavonoids & + & + & + & + \\
\hline 6 & Saponins & + & + & + & + \\
\hline 7 & Polyphenols & + & + & + & + \\
\hline 8 & Tannins & + & + & - & - \\
\hline 9 & Proteins and Amino acids & + & + & - & - \\
\hline 10 & Terpenoids & - & - & - & + \\
\hline 11 & Triterpenoids & - & - & - & + \\
\hline 12 & & & &
\end{tabular}

HRS - Hibiscus rosa sinensis 
the container and in ziplock polypack. The sample stored in the plastic container shows reduced yeast and mould growth than stored in the ziplock polypack.

\section{6 opularization of Hibiscus Flower Based Products}

The formulated products using hibiscus flowers were popularized among the selected subjects. The nutritional awareness was also created to all the subjects. A questionnaire was given to these subjects before and after the nutrition education and the nutritional knowledge of the subjects were determined.

Table 4. Extractive and ash values of fresh and dry HRS flowers

\begin{tabular}{|c|c|c|c|}
\hline \multirow{2}{*}{ S.No } & \multirow{2}{*}{ Parameters } & \multicolumn{2}{|c|}{ Values \% (W/W ) } \\
\cline { 2 - 4 } & Total Ash & Fresh Flowers & Dried Flowers \\
\hline 1 & Acid Insoluble Ash & $8.3 \%$ & $8.5 \%$ \\
\hline 2 & Water Insoluble Ash & $5.11 \%$ & $0.13 \%$ \\
\hline 3 & Sulphated Ash & $0.20 \%$ & $5.39 \%$ \\
\hline 4 & Water Soluble Extractive Value & $22.1 \%$ & $0.19 \%$ \\
\hline 5 & Alcohol Soluble Extractive Value & $6.5 \%$ & $21.8 \%$ \\
\hline 6 & Loss on Drying / Moisture Content & $5.45 \%$ & $6.2 \%$ \\
\hline 7 & \multicolumn{2}{|}{} \\
\hline
\end{tabular}

HRS - Hibiscus rosa sinensis

Table 5. Bacterial count of hibiscus flower powder

\begin{tabular}{|c|c|c|c|c|}
\hline \multirow{2}{*}{ S.No } & \multirow{2}{*}{ Sample Name } & \multicolumn{2}{|c|}{ Total Bacterial Count $(\mathrm{cfu} / \mathrm{g})$} \\
\cline { 3 - 4 } & & Initial Day & 15th Day & 30th Day \\
\hline 1 & Hibiscus ( C ) & $1.4 \times 10^{3}$ & $2.9 \times 10^{3}$ & $3.7 \times 10^{3}$ \\
\hline 2 & Hibiscus ( Z ) & $1.2 \times 10^{3}$ & $2.6 \times 10^{3}$. & $3.3 \times 10^{3}$ \\
\hline
\end{tabular}

(C) - Container (Z) - Ziplock Polypack

Table 6. Yeast and mould count of hibiscus flower powder

\begin{tabular}{|c|c|c|c|c|}
\hline \multirow{2}{*}{ S.No } & \multirow{2}{*}{ Sample Name } & \multicolumn{2}{|c|}{ Total Yeast and Mould Count ( cfu / g ) } \\
\cline { 3 - 5 } & & Initial Day & 15th Day & 30th Day \\
\hline 1 & Hibiscus ( C ) & $1.1 \times 10^{4}$ & $1.9 \times 10^{4}$ & $2.7 \times 10^{4}$ \\
\hline 2 & Hibiscus ( Z ) & $1.2 \times 10^{4}$ & $2.1 \times 10^{4}$. & $2.9 \times 10^{4}$ \\
\hline
\end{tabular}

(C) - Container (Z) - Ziplock Polypack

Table 7. Evaluation of nutritional knowledge on hibiscus flowers

$$
\mathrm{N}=30
$$

\begin{tabular}{|c|c|c|c|c|c|}
\hline \multirow{2}{*}{ S.No } & \multirow{3}{*}{ Grades } & \multicolumn{4}{|c|}{ Knowledge Scores On Hibiscus Flowers } \\
\cline { 3 - 6 } & & \multicolumn{2}{|c|}{ Before Education } & \multicolumn{2}{c|}{ After Education } \\
\cline { 2 - 6 } & & No & Percent (\%) & No & Percent(\%) \\
\hline 1 & $1-10$ & 22 & 73 & 5 & --- \\
\hline 2 & $11-20$ & 8 & 27 & 25 & 83 \\
\hline 3 & $21-30$ & --- & --- & \\
\hline
\end{tabular}


The above table revealed that the nutrition education about the importance of hibiscus flowers had created a great impact among the selected subjects.

\section{Conclusion}

Hence the present study concluded that the hibiscus flowers were rich in many phytochemicals and it can be used to treat various disease conditions. Among the hibiscus flower based formulated products the Mix (podi) was rich in most of the nutrients than that of other products. The nutrition education and popularization of the products using hibiscus flower in the form of syrup and powder proved effective in improving the nutritional knowledge of the subjects. The storage stability of dry hibiscus powder shows limited bacterial and yeast and mould counts and hence it can be stored for 30 days.

\section{References}

1. Sobhy EA, Khadiga G, Elaleem A, Hagir G. Potential antibacterial activity of Hibiscus rosa sinensis linn flowers extracts. Int J Curr Microbiol App Sci. 2017; 6(4): 1066-72https://doi.org/10.20546/ ijcmas.2017.604.132

2. Council of Scientific and Industrial Research (CSIR). The Wealth of India: A Dictionary of Indian Raw Materials and Industrial Products. First Supplement Series; 1992. p. 52-4.

3. Ragunathan V, Sulochana N. A new flavonol biasside form the flowers of Hibiscus vitifoluis Linn and its hypoglycemic activity. J India Chem Soc. 1994; 71: 705-6.

4. Jain CM, Bharathi K. Critical review of scientific validity of indigenous female contraceptive drugs described in Ayurvedic literatura. Indian Journal of Traditional Knowledge. 2011; 10(4): 678-81.

5. Gilani AH, Bashir S, Janbaz KH, Shah AJ. Presence of cholinergic and calcium channel blocking activities explains the traditional use of Hibiscus rosa sinensis in constipation and diarrea. Ethnopharmacol. 2005; 102(2): 289-94. PMid: 16182481. https://doi. org/10.1016/j.jep.2005.07.023

6. Begum Z, Younus I, Ali SM. Anti-inflammatory, analgesic and anti-pyretic activities of Hibiscus rosa sinensis linn and phytochemicals. World Journal of Pharmacy and Pharmaceutical Sciences. 2015; 4(12): $116-23$

7. Essiett UA, Iwok ES. Floral and leaf anatomy of hibiscus species. American Journal of Medical and Biological Research. 2014; 2(5): 101-17. https://doi. org/10.12691/ajmbr-2-5-1

8. Uddin B, Hossan T, Paul S, Ahmed T, Nahar T, Ahmed S. Antibacterial activity of the ethanol extracts of Hibiscus rosa sinensis leaves and flowers against clinical isolates of bacteria. Bangladesh. J Life Sci. 2010; 22: 65-73. 